ISSN 2078-6441. Вісник Львівського університету. Серія географічна. 2014. Випуск 47. С. 136-145. Visnyk of the Lviv University. Series Geography. 2014. Issue 47. P. 136-145.

$39: 911.3(=161.2: 1-87)$

\author{
ндрій убик \\ ьвівський н ціон льний університет імені в н \\ вул. . орошенк , 41, 79000, м. ввів, кр їн
}

пр цюв ння результ тів переписів н селення $є$ в жливою скл довою суспільногеогр фічних досліджень укр їнської ді спори. ро н лізов но основні етнокультурні критерії, які використовують у перепис х н селення. х р ктеризов но особливості їхнього з стосув ння у 27 кр їн х, у яких прожив є численн укр їнськ ді спор .

ля потреб суспільно-геогр фічних досліджень укр їнської ді спори виділено і сх р ктеризов но основні етнокультурні критерії, з якими можн ідентифікув ти укр їнців. окрем , це етнічний т мовний критерії. иділено три групи кр їн 3 особливостями використ ння етнічного критерію, чотири - $з$ використ нням мовного.

підст ві опр цюв ння прогр м переписів н селення викон но типологіз цію кр їн щодо інформ тивної скл дової стосовно чисельності укр їнців. цим критерієм виділено три групи кр їн: кр їни, де 3 результ т ми переписів н селення чисельність укр їнців можн визн чити точно; кр їни, де 3 результ т ми переписів н селення чисельність укр їнців можн визн чити приблизно; кр їни, де з результ т ми переписів н селення чисельність укр їнців визн чити нем є змоги.

лючові слов : перепис н селення, етнокультурний критерій, етномовний критерій, рідн мов , дом шня мов , етнічн н лежність.

оцінк ми н уковців, поз меж ми кр їни прожив є від 11 до 15 мільйонів укр їнців, укр їнськ ді спор є однією з н йчисленніших у світі [1, с. 40]. иокремити укр їнців серед предст вників інших н ціон льностей можн 3 мовою, кр їною походження чи н ціон льністю. ку змогу д $є$ опр цюв ння переписів н селення. ереписи н селення проводять м йже в усіх кр їн х світу, їхні д ні публікують н с йт х упр влінь ст тистики чи електронних ресурс х, які присвячені перепису. е менш в жливими джерел ми д них є друков ні ст тистичні вид ння з м тері л ми переписів.

метою дет льного дослідження середовищ з рубіжних укр їнців пріоритетним 3 вд нням є опр цюв ння переписів н селення, які проводили в кр їн х їхнього прожив ння. утність проблеми в тому, що ці переписи вели з різними прогр м ми, у яких були різні етнокультурні пок зники. рім того, переписи проводили в різні роки, тому н уково не є коректним пряме підсумовув ння м тері лів різних переписів про кількість укр їнців з кордоном. отрібно звести їх усіх до єдиного “зн менник ".

ереписи н селення є в жливим джерелом інформ ції для н уковців різних г лузей: геогр фів, економістів, ст тистиків, демогр фів. роблем ми розробки методологічних з с д ст тистичного вивчення н селення 3 йм лися вітчизняні н уковці . онд р, · ер сименко, . л дун, . олов ч, . узьменко, . іб нов , . ишиленко, . нікієнко, . с уленко, . рфенцев , . илипенко, . вець т з рубіжні вчені . озулов, . буз н, . енк’ю, . олоу й ін.

(C) убик ., 2014 
йвідомішими дослідник ми проблем укр їнської ді спори є . инниченко, втух, . ст вний, . к p, . леп ков. еред укр їнських учених, які зробили зн чний внесок у вивчення укр їнської ді спори, н звемо . отуш нського, . довенк , . дзя, . оломієць, . гутов , . упул , . ркуся, . ерфі, . ірен, . ендюк, . ом нюк, . емк, . ополигу, . рощинського, . евченк т ін.

кр їнські вчені розробили нові підходи до вивчення мігр ційних процесів, дослідили інституційні з с ди життя з рубіжних укр їнців. н чн ч стин пр ць присвячен історії формув ння ді спори, пр вовим спект м діяльності укр їнських орг ніз цій чи дослідженню укр їнської мови в середовищі з рубіжних укр їнців.

лодослідженими спект ми є вивчення методики проведення переписів, н ліз етнокультурних пок зників, які використовують у перепис х н селення. ершочергове з вд ння - опр цюв ння результ тів переписів т співпр ця 3 з кордонними укр їнськими гром дськими орг ніз ціями щодо тих етнокультурних критеріїв, які не ввійшли до прогр ми переписів.

ш мет - виділити т сх р ктеризув ти основні етнокультурні критерії, які використовують у прогр м х переписів, про н лізув ти етнокультурні критерії, внесені в прогр ми переписів кр їн світу, де прожив є зн чн ч стк укр їнців.

сновним джерелом інформ ції в етнічній геогр фії $є$ переписи н селення, які відбув ються у більшості кр їн світу. ереписи н селення охоплюють м йже все н селення кр їни, їхні результ ти ст ють цінним джерелом інформ ції для н уковців з різних кр їн [2, с. 166-169].

вропейськ ст тистичн комісія д $є$ т ке визн чення перепису н селення: ерепис н селення визн чений як 3 ходи, які д ють змогу проводити через регулярні інтерв ли ч су офіційний облік кількості н селення, що прожив є н території кр їни, поряд з інформ цією про соці льні т демогр фічні х р ктеристики всього н селення [5, с. 7].

тнокультурні х р ктеристики, з звич й, м ють суб'єктивну скл дову, досліджув ні групи н селення в б г тьох вип дк х є нечисленними. гідно з д ними різном нітних комісій , iнформ ція про етнокультурні х р ктеристики н селення приверт $є$ щор зу більшу ув гу урядів б г тьох кр їн, передусім у контексті здійснення політики в г лузі мігр ції, інтегр ції і меншин [3, с. 138]. еред етнокультурних озн к н селення н йч стіше виділяють етнічну н лежність (н ціон льність), мову т віровизн ння.

продовж ст. поступово виділилися н йв жливіші етнокультурні пок зники, які доцільно використовув ти в прогр м х переписів н селення. утність цих пок зників відобр жено, зокрем , в рекоменд ціях онференції європейських ст тистиків ( ) щодо переписів н селення т житлового фонду (див. т бл. 1).

тже, етнічність людини передусім розуміють як спільність історії, території т культури. ля н лізу мовного скл ду н селення рекомендов но чотири б зові мовні критерії, для н лізу віровизн ння - чотири.

нформ цію про етнічний скл д н селення чи визн чених підгруп н селення збир ють у кр їн х, де прожив ють предст вники різном нітних етнічних груп чи зн чн кількість іммігр нтів.

пров дження певного пок зник в переписи н селення д $€$ змогу н лізув ти етнокультурну ситу цію в кр їні, у тому числі в територі льному розрізі. г лом рекомендує формулюв ти прин ймні дв пит ння, що стосуються мови опитув ного. дне пит ння м є стосув тися озн к “", “б” бо “в”, інше - озн ки “г” [4, с. 12]. контексті дослідження укр їнської ді спори визн ч льним критерієм буде пит ння, яке стосується мови респондент . 
екомендов ні етнокультурні критерії у перепис х н селення

\begin{tabular}{|c|c|}
\hline $3 \mathrm{H} \mathrm{K}$ & р ктув ння озн ки і рекомендов ні критерії \\
\hline тнічн н лежність & $\begin{array}{l}\text { є грунтув тися н спільному розумінні історії т територі льного } \\
\text { походження (регіон льного, н ціон льного) етнічної групи чи общини, } \\
\text { т кож н особливих культурних х р ктеристик х, т ких як мов , i/ бо } \\
\text { віровизн ння, i/ бо особливі звич ї чи побут }\end{array}$ \\
\hline ов & $\begin{array}{l}\text { ) рідн мов, як визн чен як перш мов, з своєн вдом у р н- } \\
\text { ньому дитинстві; } \\
\text { б) основн мов , як визн чен як мов, якою особ володіє н йліпше; } \\
\text { в) мов (и), н йбільш використовув н (використовув ні) вдом і/ бо } \\
\text { н роботі; } \\
\text { г) зн ння мови (мов), яке визн чене як зд тність розмовляти і/ бо } \\
\text { пис ти (однією чи декільком мов ми) }\end{array}$ \\
\hline іровизн ння & $\begin{array}{l}\text { ) форм льн н лежність до церкви чи релігійної общини; } \\
\text { б) с моототожнення з визн ченим віровизн нням, релігійною } \\
\text { общиною чи конфесією; } \\
\text { в) релігійне вірув ння; } \\
\text { г) релігія, у яку н вернули особу }\end{array}$ \\
\hline
\end{tabular}

кл дено 3 [5, с. 137-142].

о прогр ми переписів здебільшого входить один 3 двох головних мовних критеріїв: рідн мов чи розмовн мов н селення, бо ж різном нітні модифік ції цих критеріїв. ідше реєструють другу мову, якою людин вільно володіє, рівень володіння мовою, мову, якою розмовляють вдом , рівень гр мотності.

нші, крім рідної т розмовної мови, мовні критерії ( бо ж їхні модифік ції) у прогр м х переписів н селення тр пляються доволі неч сто. хня появ з звич й зумовлен місцевими особливостями розвитку мовної ситу ції. прикл д, пит ння про мову гр мотності може з'явитися в прогр мі перепису н селення регіону, який $\epsilon$ (чи був у нед лекому минулому) колонією іншої держ ви, й шкільну освіту в ньому н д в ли не рідною мовою н селення, мовою титульного етносу [5, с. 12-14].

г лом м йже в усіх кр їн х, де прожив є укр їнськ ді спор переписи н селення відбув ються з періодичністю р з у десять років. иняток ст новлять н д й встр лія, де перепис н селення відбув ється що п’ять років.

рогр ми переписів н селення в деяких кр їн х не передб ч ють етнокультурних пок зників. е, зокрем , т кі кр їни, як р нція, сп нія, т лія, р зилія, ргентин ,

p гв й, ругв й. е зумовлено конкретними причин ми: нечисленністю н ціон льних меншин, уст леною тр дицією проведення переписів н селення, політичними обст вин ми тощо.

кр їн х, що колись були союзними республік ми колишнього , прогр ми переписів здебільшого усп дкув ли етнокультурні пок зники з прогр м переписів колишнього , зокрем , перепису 1989 р. е “н ціон льність”, “рідн мов ”, “інш мов , якою володіє респондент".

ля н лізу ст тистичної основи дослідження ми обр ли 27 кр їн, у яких живе зн чн ч стк з рубіжних укр їнців.

т бл. 2 н ведено прикл ди використ ння етнокультурних критеріїв у прогр м х переписів різних кр їн світу. 
икорист ння етнокультурних критеріїв у прогр м х переписів н селення

\begin{tabular}{|c|c|c|}
\hline p їн & $\begin{array}{l}\text { оки проведення } \\
\text { переписів н селення } \\
\begin{array}{ll}\text { (кінець -поч ток } \\
\text { ст.) } \\
\end{array}\end{array}$ & $\begin{array}{l}\text { тнокультурний критерій, } \\
\text { який включ ють прогр му перепису }\end{array}$ \\
\hline 1 & 2 & 3 \\
\hline встр лія & 2006, 2011 & $\begin{array}{l}\text { оходження респондент ; володіння рідною } \\
\text { мовою; володіння іншими мов ми; релігія, яку сповідує } \\
\text { респондент }\end{array}$ \\
\hline зерб йдж н & $1989,1999,2009$ & ціон льність, рідн мов опитув ного \\
\hline ілорусь & 1989, 1999, 2009 & $\begin{array}{l}\text { ціон льність; рідн мов опитув ного; володіння } \\
\text { російською т білоруською мов ми; мов , якою } \\
\text { розмовляють вдом ; володіння іншими мов ми }\end{array}$ \\
\hline p зилія & $1991,1996,2000,2010$ & сов н лежність опитув ного \\
\hline $\begin{array}{l}\text { елик } \\
\text { рит нія* }\end{array}$ & $1991,2001,2011$ & $\begin{array}{l}\text { ціон льн ідентичність; н лежність до етнічної } \\
\text { групи; рідн мов ; володіння нглійською; релігія, яку } \\
\text { сповідує респондент }\end{array}$ \\
\hline ірменія & $1989,2001,2011$ & $\begin{array}{l}\text { ціон льність; рідн мов опитув ного; інш } \\
\text { мов , якою опитув ний вільно володіє; релігія, яку } \\
\text { сповідує респондент }\end{array}$ \\
\hline рузія & 1989,2002 & $\begin{array}{l}\text { ціон льність; рідн мов опитув ного; володіння } \\
\text { іншими мов ми, релігія, яку сповідує респондент }\end{array}$ \\
\hline стонія & $1989,2000,2011-2012$ & $\begin{array}{l}\text { ціон льність; рідн мов ; володіння н річчям, } \\
\text { говором бо ді лектом; володіння іншою мовою, крім } \\
\text { рідної }\end{array}$ \\
\hline сп нія & $1991,2001,2011$ & ціон льність опитув ного, гром дянство \\
\hline т лія & $1991,2001,2011$ & $\begin{array}{l}\text { ціон льність опитув ного, гром дянство, релігія, } \\
\text { яку сповідує респондент }\end{array}$ \\
\hline $3 \mathrm{XcT} \mathrm{H}$ & 1989, 1999, 2009 & $\begin{array}{l}\text { ціон льність; рідн мов опитув ного; зн ння } \\
\text { респондентом к } 3 \text { хської, російської й нглійської мов; } \\
\text { віросповід ння респондент }\end{array}$ \\
\hline Н Д & $\begin{array}{c}1991,1996,2001,2006, \\
2011\end{array}$ & $\begin{array}{l}\text { міння спілкув тися нглійською т фр нцузькою } \\
\text { мов ми; н йбільш використовув н мов вдом ; вміння } \\
\text { говорити іншими мов ми вдом ; мов , яку особ } \\
\text { вперше вивчил вдом в дитинстві і досі розуміє; } \\
\text { етнічн н лежність }\end{array}$ \\
\hline иргизст н & $1989,1999,2009$ & $\begin{array}{l}\text { ціон льність; рідн мов опитув ного; володіння } \\
\text { іншими мов ми }\end{array}$ \\
\hline твія & 1989, 2000, 2011 & $\begin{array}{l}\text { ціон льність; мов , якою респондент розмовляє } \\
\text { вдом ; використ ння ді лектів }\end{array}$ \\
\hline итв & 1989, 2001, 2011 & $\begin{array}{l}\text { ціон льність; рідн } \\
\text { говорити/пис ти іншими мов ми; релігія чи конфесія, } \\
\text { до якої н лежить респондент }\end{array}$ \\
\hline олдов & 1989,2004 & $\begin{array}{l}\text { ціон льність; рідн мов ; мов , якою з звич й } \\
\text { говорять удом ; інші мови, якими володіє респондент; } \\
\text { релігія, яку сповідує респондент }\end{array}$ \\
\hline ел ндія & 2006,2011 & $\begin{array}{ccc}\text { тнічн } & \text { н лежність; розмовн мов ; } & \text { кр їн } \\
\text { походження, релігія, яку сповідує респондент } & \end{array}$ \\
\hline
\end{tabular}




\begin{tabular}{|c|c|c|}
\hline 1 & 2 & 3 \\
\hline ольщ & $1988,2002,2011$ & ціон льність, мов якою розмовляють вдом \\
\hline ортуг лія & $1991,2001,2011$ & $\begin{array}{l}\text { ціон льність опитув ного, релігія, яку сповідує } \\
\text { опитув ний }\end{array}$ \\
\hline осія & $1989,2002,2010$ & $\begin{array}{rrr}\text { ціон льність; володіння } & \text { російською } & \text { мовою; } \\
\text { володіння іншими мов ми; рідн } & \text { мов } & \\
\end{array}$ \\
\hline умунія & $1992,2002,2011$ & $\begin{array}{l}\text { лежність до етнічної групи, рідн мов , релігія, } \\
\text { яку сповідує респондент }\end{array}$ \\
\hline лов ччин & $1991,2001,2011$ & $\begin{array}{l}\text { ціон льність; рідн мов ; мов , яку н йбільше } \\
\text { використовують публічно; мов , якою користуються } \\
\text { вдом }\end{array}$ \\
\hline & $1990,2000,2010$ & $\begin{array}{l}\text { с респондент ; володіння нглійською мовою; } \\
\text { використ ння іншої, ніж нглійськ , вдом ; етнічн } \\
\text { н лежність }\end{array}$ \\
\hline Джикист н & $1989,2000,2010$ & $\begin{array}{l}\text { ціон льність; рідн мов опитув ного; інші мови, } \\
\text { якими опитув ний вільно володіє }\end{array}$ \\
\hline збекист н & 1989 & ціон льність, рідн мов опитув ного \\
\hline ехія & $1991,2001,2011$ & $\begin{array}{l}\text { ціон льність; рідн мов опитув ного; релігія, } \\
\text { яку сповідує респондент }\end{array}$ \\
\hline уркменіст н & 1989, 1995, 2012 & $\begin{array}{l}\text { ціон льність; рідн мов опитув ного; володіння } \\
\text { іншими мов ми }\end{array}$ \\
\hline
\end{tabular}

* нглія й ельс, отл ндія т івнічн рл ндія переписи н селення проводять окремо. ут ін д лі з мість еликої рит нії розуміти нглія т ельс.

кл дено $з$ [6-31].

тнічн н лежність опир ється н 3 г льне розуміння історії т територі льного походження (регіон льного, н ціон льного) етнічної групи чи общини, т кож н особливі культурні х р ктеристики, т кі як мов i/ бо віросповід ння, i/ бо особливі звич ї т укл д життя, що відрізняються від решти н селення. використ нням критерію етнічної н лежності у прогр м х перепису кр їни, н ведені у т бл. 2, можн розподілити н три групи: кр їни, що використовують критерій етнічної н лежності; кр їни, що використовують критерій н ціон льності; кр їни, що не використовують прямого етнічного критерію (т бл. 3).

озподіл кр їн з критерієм етнічної н лежності

блиця 3

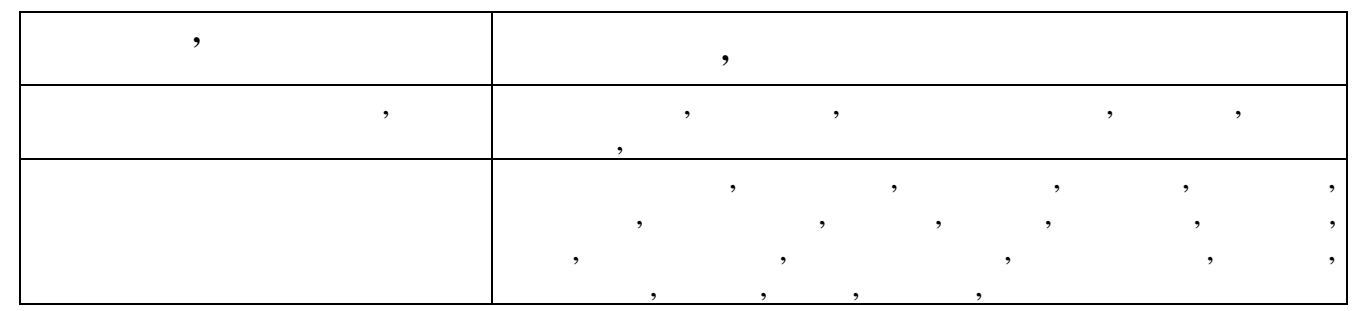

кл дено 3 [6-31].

ерш груп - це кр їни, які тр диційно прийм ють іммігр нтів. кож у цих кр їн х прожив $€$ зн чн ч стк етнічних меншин. рім пок зників “етнічн 
н лежність” чи “н лежність до етнічної групи”, у т т зилії використовують критерій “р сов н лежність”. Зн чимо, що цей критерій не є етнокультурним. рім того, відповідь про н лежність до етнічної групи в переписі бул не обов'язковою. переписних лист х встр лії т ової ел ндії сформульов не 3 пит ння про кр їну походження респондент . етнічної групи” доповнили пит нням про походження 6 тьків.

редст вник ми другої групи є кр їни колишнього т хідної вропи, де цей пок зник сформульов ний як “н ціон льність” респондент . од тково сюди входять ортуг лія, сп нія, т лія.

використ нням критерію мовної н лежності в прогр м х перепису кр їни, н ведені у т бл. 2, можн розділити н т кі групи: 1) кр їни, що використовують критерій “рідн мов ”; 2) кр їни, що використовують критерій “мов (и), н йбільш використовув н вдом i/ бо н роботі”; 3) кр їни, що не використовують мовного критерію; 4) кр їни, що використовують критерій “володіння іншими мов ми” (т бл. 4).

блиця 4

озподіл кр їн з мовним критерієм

\begin{tabular}{|c|c|}
\hline овний критерій & р їни, які його використовують \\
\hline $\begin{array}{l}\text { олодіння рідною мовою, рідн } \\
\text { мов опитув ного }\end{array}$ & $\begin{array}{l}\text { встр лія, осія, , зерб йдж н, ілорусь, елик } \\
\text { рит нія, ірменія, рузія, стонія, з хст н, иргизст н, } \\
\text { итв , олдов , ольщ, осія, умунія, лов ччин , } \\
\text { джикист н, збекист н, ехія }\end{array}$ \\
\hline $\begin{array}{l}\text { ов (и), н йбільш використо- } \\
\text { вув н (використовув ні) вдом } \\
\text { i/ бо н роботі }\end{array}$ & $\begin{array}{cc}\text { ілорусь, н д , твія, олдов , ов ел ндія, ольщ , } \\
\text { лов ччин , }\end{array}$ \\
\hline олодіння іншими мов ми & $\begin{array}{c}\text { встр лія, ілорусь, ірменія, рузія, стонія, з хст н, } \\
\text { н д , иргизст н, итв , олдов, осія, уркменіст н }\end{array}$ \\
\hline
\end{tabular}

кл дено 3 [6-31].

икорист ння мовного пок зник в перепис х н селення з лежить від особливостей проведення переписів. звич й, кр їни, згідно з екоменд ціями , поєднув ли дв мовні пок зники: “рідн мов” т “володіння іншими мов ми” бо “рідн мов " і “мов (и), н йбільш використовув н (використовув ні) вдом i/ бо н роботі”.

йч стіше з стосовув ли пок зник "рідн мов ” кр їни колишнього (з винятком твії), хідної вропи ( умунія, олдов , ехія, ольщ, лов ччин ), встр лія, елик рит нія. ит ння про основну мову (мову, якою респондент володіє н йліпше) було сформульов не у переписних лист х

переписних лист х н ди, твії, лов ччини вміщено пит ння про використ ння мови (мов) вдом i/ бо н роботі.

дним з рекомендов них мовних критеріїв є “зн ння мови (мов), які визн чені як зд тність говорити i/ бо пис ти однією чи декільком визн ченими мов ми”. цьому спекті в жко виділити територі льну з кономірність. прикл д: н д - пит ння про вміння спілкув тися нглійською чи фр нцузькою мов ми (є можливість з зн чити інший в рі нт), 3 хст н - зн ння к 3 хської, російської т нглійської мов; ілорусь - володіння білоруською т російською мов ми; осія - володіння російською мовою (хоч в переписному листі фігурує пит ння “рідн мов ”), елик рит нія володіння нглійською мовою. г лом у переписних лист х кр їн цієї групи 
сформульов не з пит ння про зн ння цих мов. переписних лист х інших кр їн пит ння сформульов не т к: “інші мови, якими володіє респондент".

к з зн чено у т бл. 1, згідно з рекоменд ціями кр їни можуть використовув ти чотири критерії віровизн ння. г лом дод тковий критерій віровизн ння зводиться до розмежув ння різном нітних можливих підходів до нього: 1) офіційн н лежність до церкви чи релігійної общини; 2) уч сть у житті церкви; 3) віровизн ння.

кож $з$ зн чено, що т м, де з д ють одне з пит ння, пропонують збир ти д ні про “офіційну н лежність до церкви чи релігійної общини”, дозволивши респондент м д ти відповідь “ні”. г лом десять кр їн використ ли в перепис х н селення критерій віросповід ння. итв, стонія т ірменія сформулюв ли з пит ння згідно з рекоменд ціями “офіційн н лежність особи до віри чи до релігійної общини”. ов

ел ндія, з хст н, рузія, елик рит нія, встр лія м ють у переписних лист х гр фу “релігія", де респондент м є змогу декл рув ти своє віровизн ння, вибр вши один з пропонов них в рі нтів, відмовитись від відповіді, вк з ти інший в рі нт, якого нем є в переписному листі. олдові т ехії респонденти с мі з зн ч ють своє віросповід ння.

тже, н підст ві н лізу ст тистичної основи суспільно-геогр фічного дослідження укр їнської ді спори, н н ш погляд, кр їни, у яких живе численн укр їнськ меншин, 3 особливостями етнокультурних критеріїв у прогр м х переписів можн розділити н три групи.

1. $\mathrm{p}$ їни, де з д ними переписів кількість укр їнців можн визн чити більш-менш точно. звич й, це кр їни, у прогр м х переписів яких є прямий етнічний критерій,

в переліку етнічних груп у переписному листі є укр інці. рім того, ч сто є т кож інші критерії (мовний, релігійний), що д є змогу дет льніше про н лізув ти укр їнську меншину в кр їні.

ю групу можн розділити н дві підгрупи:

- кр їни, де в прогр м х переписів етнічний критерій сформульов но як "етнічн н лежність”. окрем , це т кі кр їни: встр лія, елик рит нія, , ов ел ндія Т н д ;

- кр їни, де в прогр м х переписів етнічний критерій сформульов но як “н ціон льність”. о них н леж ть зерб йдж н, ілорусь, ірменія, рузія, стонія, з хст н, иргизст н, твія, итв , олдов , ольщ, осія, лов ччин , джикист н, збекист н, ехія, ортуг лія, сп нія, т лія, умунія, уркменіст н.

2. р їни, де 3 д ними переписів кількість укр їнців можн визн чити приблизно, з більшим чи меншим ступенем точності. звич й це кр їни, прогр ми переписів яких критерію етнічності (н ціон льності) не м ють, проте введено мовний критерій. переліку мов у переписному листі $€$ укр їнськ. ут у р зі визн чення кількості укр їнців потрібно вр ховув ти що, можливо, їхня ч стин зберегл етнічну ідентичність, проте втр тил мову. обто ре льн кількість укр їнців може бути більшою.

ю групу розділено н три підгрупи:

- кр їни, де в прогр м х переписів мовний критерій сформульов но як “рідн мов ". окрем , це т кі кр їни: встр лія, осія, , зерб йдж н, ілорусь, елик рит нія, ірменія, рузія, стонія, з хст н, иргизст н, итв , олдов , ольщ , осія, умунія, лов ччин, джикист н, збекист н, ехія, уркменіст н;

- кр їни, де в прогр м х переписів мовний критерій сформульов но як “володіння іншими мов ми”. ей етномовний критерій використовують т кі кр їни: встр лія, ілорусь, ірменія, рузія, стонія, з хст н, н д, иргизст н, итв, олдов осія, уркменіст н; 
- кр їни, де в прогр м х переписів мовний критерій сформульов но “мов (и) н йбільш використовув н вдом i/ бо н роботі”. p їни, у переписних лист х яких використовують цей критерій, т кі: ілорусь, н д, твія, олдов , ов ел ндія, ольщ , лов ччин , , джикист н.

3. р їни, де з д ними переписів кількість укр їнців визн чити нем є змоги. обто це кр їни, у яких бо вз г лі нем є етнокультурної переписної ст тистики, бо ж у м тері л х етнокультурної ст тистики не виділено окремої групи “укр їнці” чи окремо носіїв укр їнської мови. окрем, це т кі кр їни: р зилія, ргентин,

р гв й, ругв й, р нція.

одо т ких кр їн можн використовув ти м тері ли про гром дянство, які $\epsilon$ в прогр м х м йже всіх переписів. ким способом можн визн чити приблизно прин ймні кількість предст вників ост нньої хвилі укр їнської мігр ції. ншими джерел ми можуть бути м тері ли поточної ст тистики, зокрем , ст тистики мігр цій, д ні релігійних орг ніз цій т ін.

овний пок зник у перепис х окреслений чотирм критеріями: рідн мов ; основн мов , якою особ н йліпше володіє; н йбільш використовув ні мов (мови) вдом чи н роботі; зн ння іншої мови (мов), що н д лі ускл днює підр хунок. цьому пл ні кр їни колишнього т хідної вропи є окремою групою, у переписних лист х фігурує критерій “рідн мов”. оширеним явищем $є$ з пит ння про зн ння чи володіння конкретною мовою. переписних лист х використовують критерії “" $і$ “ "Г" (див. т бл. 1), винятком є переписні листи ілорусі т 3 хст ну, де пок зник “ $Г$ ” уточнений: з питують про зн ння білоруської т російської мов й к з хської, російської т нглійської мов, відповідно. н д, вр ховуючи специфіку свого н селення, формулює з пит ння про зн ння нглійської т фр нцузької мов.

1. $\mathrm{cm}$ вний . . кономічн і соці льн геогр фія кр їни : н вч. посібник / . . ст вний. - . : орум, 2001. -239 с.

2. убик . . тнокультурні пок зники у прогр м х переписів н селення (для потреб етногеогр фічних досліджень) / . . убик // еогр фічн н ук і пр ктик : виклики епохи : м тері ли іжн р. н ук. конф., присвяченої 130-річчю геогр фії у ьвівському університеті (м. ьвів, 16-18 тр вня 2013 р.) / 3 т. - ьвів : ид вничий центр імені в н р нк , 2013. - . 1. - . 166-169.

3. ушнер ( нышев) . . тнические территории и этнические гр ницы / . . ушнер. - . : зд-во , 1951.-256 с.

4. озинський. . еогр фія мов в кр їні : н вч. посібник / . . озинський. ьвів : ввів, 2012. - 146 с

5. екоменд ции конференции европейских ст тистиков по проведению переписи н селения и жилищного фонд 2010 год / вропейск я ст тистическ я комиссия. ью- орк; енев , 2006. - 296 с.

6. Australian Bureau of Statistics [ лектронний ресурс]. - ежим доступу: http://www.abs.gov.au.

7. Azbaycan Respublikasinin D vlt Statistik a Komitsi [ лектронний pecypc]. - ежим доступу: http://www.azstat.org.

8. Biraul National de Statistică al Republici Moldova [ лектронний ресурс]. - ежим доступу: http://www.statistica.md. 
9. Eesti Statistika [ лектронний ресурc]. - ежим доступу: http://www.stat.ee.

10. Instituto Brasiliero de Geografiae Estatistica [ лектронний pecypc]. - ежим доступу: http:// www.ibge.gov.br.

11. Instituto National de Estadistica [ лектронний pecypc]. - ежим доступу: http://www.ine.es.

12. Instituto National de Estatistica [ лектронний pecypc]. - ежим доступу: http://www.ine.pt.

13. Institutul National de Statistica [ лектронний pecypc]. - ежим доступу: http://www.insse.ro/cms/rw/pages/rpl2002.

14. Istat [ лектронний ресурc]. - ежим доступу: http://www.istat.it.

15. Lietuvos Statistikos Departamentas [ лектронний pecypc]. - ежим доступу: http://www.stat.gov.lt.

16. O‘zbekiston Respublikesi Davlat statisticaqo'mitasi [ лектронний ресурс]. - ежим доступу: http://www.stat.uz.

17. Office for National Statistics [ лектронний pecypc]. - ежим доступу: http://www.ons.gov.uk/ons/index.html.

18. Štatistický úrad Slovenskej Republiky [ лектронний pecypc]. - ежим доступу: http://portal.statistics.sk.

19. Statistical Society of Canada [ лектронний pecypc]. - ежим доступу: http://www.ssc.ca.

20. Statistics New Zealand [ лектронний pecypc]. - ежим доступу: http://www.stats.govt.nz.

21. United States Census Bureau [ лектронний pecypc]. - ежим доступу: http://www.census.gov.

22. гентии мори зди резиденти умхурии очикистон. осуд рственный комитет уркменист н по ст тистике [ лектронний ресурс]. - ежим доступу: http://www.stat.gov.tm.

23. з кст н еспублик сы т тистик генттігі [ лектронний ресурс]. - ежим доступу: http://www.stat.kz.

24. цион льный ст тистический комитет ыргызской еспублики [ лектронний pecypc]. - ежим доступу: http://www.stat.kg.

25. цион льный ст тистический комитет еспублики ел русь [ лектронний pecypc]. - ежим доступу: http://www.belstat.gov.by.

26. ціон льн ст тистичн служб ірменії [ лектронний ресурс]. - ежим доступу: http://www.armstat.am.

27. ціон льний ст тистичний офіс рузії [ лектронний ресурс]. - ежим доступу: http://geostat.ge.

28. едер льн я служб госуд рственной ст тистики [ лектронний ресурс]. - ежим доступу: http://www.perepis-2010.ru.

29. Latvijas Statistika [ лектронний ресурс]. - ежим доступу: http://www.csb.gov.lv/en.

30. Glówny Urząd Statystyczny [ лектронний pecypc]. - ежим доступу: http://www.stat.gov.pl/gus.

31. Český Statistický ÚŘAD [ лектронний pecypc]. - ежим доступу: http://www.czso.cz/sldb2011/eng/redakce.nsf/i/census_information.

m ття: н дійшл до ред кції 16.07.2014

доопр иьов н 12.09 .2014

прийнят до друку 15.10.2014 


\title{
STATISTICAL BASIS OF SOCIO-GEOGRAPHICAL STUDY OF UKRAINIAN DIASPORA
}

\author{
Andriy Zubyk \\ Ivan Franko National University of Lviv, \\ P. Doroshenko Str., 41, UA - 79000 Lviv, Ukraine
}

The processing of census results is an important part of social and geographical researches of Ukrainian diaspora. The aim of this article is analysis of main ethnic and cultural criteria which have been used in the census. The peculiarities of their usage in 27 countries, where is numerous Ukrainian diaspora, were described.

Main criteria for identifying of Ukrainians were defined and characterized for the purposes of sociogeographical researches of Ukrainian diaspora. Among them are ethnic and linguistic criteria. Three groups of countries on the specifics of usage of ethnic criteria and four groups of countries on the specifics of usage of language were distinguished.

The typology of countries in relation to informative component of Ukrainian population was accomplished based on studying the programs of census. According to this criterion, three groups of countries were identified: countries where the results of Ukrainian population census can be set accurately; countries where the results of Ukrainian population census can be set approximately; countries where the results of Ukrainian population census can't be determined.

Key words: census, ethno-cultural criteria, ethno-linguistic criteria, mother tongue, home language, ethnicity. 